\author{
Stanisław Liszewski
}

\title{
GENEZA I ROZWÓJ OSADNICTWA WYPOCZYNKOWEGO W OTOCZENIU ŁODZI
}

\section{LA GENESE ET LE DÉVELOPPEMENT DE LA COLONISATION DE REPOS AUX ENVIRONS DE EÓDŹ}

\begin{abstract}
Dans le travail, on a présenté la génèse de la colonisation de repos aux environs de Łódź ainsi que son développement dans les trois périodes suivantes: aviant la Tère guerre mondiale, pendant les vingt ans d'entre deux guerres, après la IIère guerre mondiale. On a montré les facteurs conditionnant la génèse de cette forme de la colonisation en citant l'accessibilité de communication et celle juridique au terrain et aussi, quoique d'une façon moins détaillée, les valeurs du milieu naturel. Les résultats des recherches faites ont démontré entre cutres le rôle important de la colonisation de repos dans le processus de l'urbanisation des terrains suburbains et la succession spatiale fortement développée de la fonction de repos aux environs de Łódź.
\end{abstract}

Współczesny etap rozwoju cywilizacji charakteryzuje $\mathrm{m}$. in. gwałtowny wzrost potrzeb rekreacyjnych i wypoczynkowych człowieka. Potrzeby te, zgłaszane przez ogół społeczeństwa, są szczególnie silnie artykułowane w środowiskach wielkomiejskich. Mieszkańcy miast wyzwoleni z obowiązku całotygodniowej pracy zarobkowej, zamknięci w betonowych mieszkaniach, coraz częściej przeznaczają swój wolny czas na wypoczynek poza miejscem stałego zamieszkania.

Efektem przestrzennym tego zapotrzebowania jest powstanie $\mathrm{w}$ otoczeniu dużych miast nowych form osadniczych, których jedyną czy główną funkcją jest funkcja wypoczynkowa.

Celem opracowania jest wyjaśnienie genezy osadnictwa wypoczynkowego w otoczeniu Łodzi, jego identyfikacja oraz określenie etapów i kierunków rozwoju tej formy osadniczej.

Wybór Łodzi do badań szczegółowych znajduje uzasadnienie w in- 
dywidualności tego miasta wynikającej z jego genezy, położenia geograficznego, tempa rozwoju oraz struktury społecznej mieszkańców (L. Str a s z e w i c z 1979). Indywidualność ta wpłynęła na przebieg procesu powstawania i rozwoju interesujących nas, form osadniczych, często hamując go lub opóźniając, zwłaszcza w początkowym okresie.

Wprawdzie Łódź, jako miasto lokacyjne, powstała jeszcze w XV w. (1423 r.), ale jej rzeczywisty rozwój jest związany $\mathrm{z}$ wiekiem XIX, a rok 1823 jest uznawany powszechnie za początek powstania Łodzi przemysłowej. W 1820 r. Łódź liczyła 767 mieszkańców, w dziesięć lat później $(1830$ r.) 4343, a pierwsze 100 tys. przekroczyła w 1884 r. (105665). Późniejszy rozwój był jeszcze gwałtowniejszy, bowiem po upływie zaledwie 30 lat (1914 r.) stan zaludnienia Łodzi zbliżył się do 0,5 mln. Współcześnie miasto liczy 850 tys. mieszkańców (1985 r.).

Ten bardzo dynamiczny rozwój demograficzny zawdzięcza miasto wyłącznie przemysłowi i to praktycznie jednej branży, przemysłowi włókienniczemu. Rozwój przemysłu stał się swoistą pompą ssącą, przyciągającą do miasta nie tylko mieszkańców okolicznych wsi i miasteczek, ale bardziej rozległego terenu.

Napływ różnorodnych grup ludności uzewnętrznił się wyraźnie w strukturach demograficznych i społecznych mieszkańców Łodzi. W 1914 r. wśród zamieszkujących miasto było 50,7\% katolików, 25,7\% ewangelików, $23,1 \%$ wyznania mojżeszowego i $0,9 \%$ prawosławnych. Zbliżona do wyznaniowej była również $w$ tym okresie struktura narodowościowa miasta.

Obok mozaiki narodowościowej i wyznaniowej, Łódź stała się także miastem ogromnych kontrastów społecznych. Spis z $1897 \mathrm{r}$. wykazał, iż wśród ludności Łodzi w wieku 10 lat i więcej, 0,26\% legitymowało się wykształceniem wyższym lub specjalnym (514 osób!), a 3,0\% posiadało wykształcenie średnie. Jednocześnie $49,46 \%$ nie umiało czytać (J. J a n c z a k 1982).

$\mathrm{Z}$ narodowością silnie korelowała na przełomie XIX i XX w. struktura zawodowa mieszkańców Łodzi. Rosjanie utrzymywali się głównie $\mathrm{z}$ pracy $\mathrm{w}$ administracji, wojsku i oświacie (proces rusyfikacji), Żydzi w $40 \%$ z handlu, Niemcy w $73 \%$ z przemysłu i rzemiosła, a Polacy w $60 \%$ z przemysłu i w $25 \%$ ze służby i zajęć domowych (J. J a n c z a k 1982).

Istniał więc w tym mieście specyficzny podział, w którym nieliczne grupy ludności rosyjskiej, niemieckiej i częściowo ży đowskiej tworzyły szczyt drabiny społecznej (zamożność, wylkształcenia, pozycja społeczna itp.), a ludność polska. w swojej masie stanowiła glówną siłę roboczą dla rozwijającego się przemysłu. "zzczyl" ten obejmował w Łodzi 
wąską tylko grupę przemysłowców, kupców, bankierów, a także najwyższych urzędników administracji państwowej. Podstawowa część mieszkańców ówczesnej Łodzi to biedota, analfabeci, o niskich zarobkach i niepewnym bycie.

Ten dynamiczny rozwój gospodarczy oraz złożoność demograficzna i społeczna, stały się charakterystycznymi cechami miasta, którego położenie greograficzne było także pod pewnymi względami wyjątkowe.

Łódź leży w strefie przejściowej pomiędzy nizinami Polski środkowej a wyżynami Polski południowej (J. D y lik 1971). Najbardziej urozmaiconą częścią tego obszaru jest strefa krawędziowa Wyżyny Łódzkiej, która przebiega na północ od Łodzi wzdłuż linii Zgierz-Brzeziny. Jako jedyne tej wielkości miasto w Polsce, nie leży ono ani nad, ani nawet w pobliżu żadnej dużej rzeki, ale na dziale wodnym Wisły i Odry. Zarówno lokacyjne miasto średniowieczne, jak i Łódź przemysłowa, powstały na terenach silnie zalesionych. Jak podaje A. P i e trz a k (1973) w okresie poprzedzającym powstanie Łodzi przemysłowej (lata 1802/ 11803), lasy zajmowały $56,2 \%$ obecnej powierzchni administracyjnej Łodzi oraz $42,6 \%$ powierzchni obszaru dzisiejszej strefy podmiejskiej. Trzydzieści lat później stopień zalesienia tych obszarów spadł odpowiednio do $30 \%$ i $30,5 \%$ (lata 1822-1839), a po dalszych stu latach (1929-1938) osiągnął wartość minimalną, tzn. 5,6\% w granicach administracyjnych dzisiejszej Łodzi, oraz $9,9 \%$ w jej strefie podmiejskiej.

Analiza środowiska geograficznego Łodzi i jej okolic wskazuje na ograniczoną atrakcyjność wypoczynkową terenu, który z upływem lat na skutek degradacji środowiska naturalnego uległ dalszemu obniżeniu (A. Ma tc z a k 1986).

Przedstawiony obraz złożonej sytuacji społecznej i gospodarczej, dynamicznie rozwijającego się centrum polskiego włókiennictwa, w konfrontacji z mało atrakcyjnym obszarem zaplecza Łodzi, stanowi punkt wyjścia do analizy rodzącego się na przełomie wieków XIX i XX zainteresowania wypoczynkiem poza miejscem zamieszkania tej półmilionowej wówczas aglomeracji miejskiej.

Należy jednocześnie pamiętać, iż obok omówionych determinant Łódź podobnie jak i cała Polska, była w XX w. terenem bardzo burzliwych i ważkich wydarzeń historycznych (odzyskanie niepodległości, okupacja hitlerowska, wyzwolenie). One to głównie wyznaczają etapy rozwaju osadnictwa wypoczynkowego w okolicach Łodzi, dzieląc go na trzy okresy: przez I wojną światową, dwudziestolecia międzywojennego oraz po II wojnie światowej. 


\section{OSADNICTWO WYPOCZYNKOWE OKOLIC ŁODZI} W OKRESIE PRZED I WOJNA SWIATOWA

Początki wypoczynku poza granicami Łodzi łączą się z rozwojem środków komunikacji masowej, które udostępniły tereny podmiejskie mieszkańcom miasta. Rozwój ten rozpoczął się uruchomieniem w $1866 \mathrm{r}$. pierwszego połączenia kolejowego Łodzi przez Koluszki z tzw. linią warszawrsko-wiedeńską. Było to przez 35 lat jedyne połączenie miasta komunikacją szynową z bliższym i dalszym zapleczem. Dopiero pierwsze lata XX w. przyniosły dalsze zmiany.

Łódź otrzymała w tym czasie liczne połączenia tramwajami podmiejskimi z pobliskimi miastami: Pabianicami (1901 r.), Zgierzem (1901 r.), Aleksandrowem (1910 r.), Konstantynowem (1910 r.) oraz Rzgowem przez Rudę Pabianicką (1910 r.). Tramwaj do Tuszyna został doprowadzony w 1917 r. Na początku wieku (1903 r.) uruchomiono również drugie połączenie kolejowe, którym była linia z Kalisza do Warszawy, przebiegająca przez Pabianice, Łódź i Zgierz. W ten sposób doszło na początku XX w. do ukształtowania podstawowej sieci komunikacji szynowej, która umożliwiła penetrację obszarów podmiejskich Łodzi m. in. w celach wypoczynkowych.

Najbardziej zamożna klasa przemysłowców, bankierów czy handlowców łódzkich, wykorzystując uruchomione w 1866 r. połączenie kolejowe, wyjeżdżała do modnych podówczas uzdrowisk Austrii, Szwajcarii, Francji czy Włoch. Były to znane z literatury "wyjazdy do wód dla poratowania zdrowia". W miarę wzrostu fortun oraz zmiany mody, coraz częstsze było zainteresowanie tej grupy społecznej podmiejskimi majątkami ziemskimi, które wykupywano od bankrutującej szlachty, zamieniając na rezydencje.

Przykładem może tu być jeden z najzamożniejszych przemysłowców łódzkich Juliusz Heinzel, który w latach osiemdziesiątych XIX w. nabył na licytacji, wówczas jeszcze podłódzki, folwark Julianów, a w latach dziewięćdziesiątych tego wieku wykupił ostatecznie $\mathrm{z}$ rąk rodziny Zawiszów dobra Łagiewnickie. W obu tych posiadłościach Heinzel posiadał pałace-rezydencje, służące celom reprezentacyjnym i wypoczynkowym. Podobny charakter, choć na mniejszą skalę, ma rezydencja Romischa wybudowana ok. 1912 r. na terenie dzisiejszego Głowna.

Cechą charakterystyczną tych pierwszych rezydencji w okolicach Łodzi był ich pałacowo-dworski charakter. Były to obickty duże, otoczone znacznymi obszarami zieleni parkowej lub leśnsj, samotne, izolowane od życia zewnętrznego. Nie tworzyły one zwartych kompleksów osadniczych, a ich usytuowanie było związane z dogodnymi dla wypo- 
czynku warunkami naturalnymi, ale również z dostępnością komunikacyjną.

Znacznie więcej elementów osadnictwa wypoczynkowego w przestrzeni greograficznej pozostawiła w tym okresie warstwa średnio zamożnych i zamożnych mieszkańców miasta.

Pierwsze, nieporadne w swojej urbanistyce i architekturze, osiedla wypoczynkowe powstały na terenach folwarku Arturów (obecnie Arturówek) oraz w pobliskich Rogach, położonych na północny wschód od centrum Łodzi przemysłowej, a także w części południowej Rudy Pabianickiej, usytuowanej na południowy zachód od miasta. Wybór tych obszarów na osadnictwo wypoczynkowe był podyktowany dogodnym położeniem komunikacyjnym oraz sprzyjającymi warunkami środowiska. W obu przypadkach osadnictwo to wkroczyło na tereny piaszczystych pagórków porośniętych lasem, a jednocześnie przeciętych dolinami rzek.

Przed I wojną światową pojawiała się także w okolicach Łodzi nowa forma wypoczynku, jaką był wyjazd na tzw. "letnisko" do pobliskich wsi i miasteczek, gdzie wynajmowano mieszkania w domach zamożniejszych rolników. Dotyczyło to $\mathrm{m}$. in. Wiśniowej Góry, zamieszkałej wówczas głównie przez ludność niemiecką i żydowską, Tuszyna, Zofijówki, Rydzynek, Głowna i innych. Z wyjazdów tych korzystała głównie średnio zamożna warstwa mieszkańców Łodzi, przy czym istniał tu podział narodowościowo-językowy. Ludność pochodzenia niemieckiego i żydowskiego wynajmowała kwatery we wsiach zasiedlonych przez kolonistów niemieckich, ludność polska wie wsiach polskich. Było to uwarunkowane względami językowo-kulturowymi. Wynajmowanie kwater na tzw. "letniska" jest początkową formą ekspansji funkcji wypoczynkowej na tereny wiejskie otaczające Łódź.

Największa ilościowo, biedna część mieszkańców Łodzi, swój wypoczynek poza miejscem stałego zamieszkania organizowała w pobliskich lasach i nielicznych terenach przywodnych. Był to wypoczynek kilkugodzinny, spędzany bezpośrednio w otoczeniu przyrody, który nie powodował powstania żadnych form osadniczych. Jak podaje B. Ko pc z y ń s k a - J a w o r s k a (1980), ludność robotnicza Łodzi wypoczywała w tym okresie głównie w parku Źródliska (najstarszy park Łodzi założony w 1840 r.), w lesie zwanym Szeląg (obecnie obszar ten jest ograniczony ul. Kopcińskiego, Armii Czerwonej i torem kolejowym), w lesie scheiblerowskim na Kowalszczyźnie (obecnie park na Młynku), na terenie tzw. Wolfówki nad rzeką Olechówką (obecnie Stawy Jana), w lasku Findera (obecnie park im. Dąbrowskiego), w parku Winecja (obecnie im. Słowackiego) i Sielanka przy tzw. szosie pabianickiej, w Rudzie Pabianickiej, w lesie Mani (późniejszy Park Ludowy), a także 
na terenach leśnych organizowanego w latach 1904-1910 parku noszącego obecnie imię Poniatowskiego.

Dłuższe, całodniowe wyprawy organizowano z Łodzi do klasztoru w Łagiewnikach oraz kapliczek św. Antoniego, św. Rocha i Sebastiana, znajdujących się w lesie w pobliżu klasztoru. Dotyczyło to pierwotnie dni odpustowych (Zielone Swiątki, dzień św. Antoniego), w późniejszym okresie cele religijne łączono $\mathrm{z}$ wypoczynkowymi, przybywając tu $\mathrm{w}$ pogodne niedziele.

Pierwszy etap rozwoju osadnictwa wypoczynkowego w okolicach Łodzi bardzo wyraźnie wskazuje na jego zależność od zamożności spoleczeństwa oraz dostępności komunikacyjnej terenów okalających miasto. Trzecim czynnikiem były walory środowiskowe terenów wypoczynkowych. W tym okresie powstają nieliczne, pojedyncze obiekty rezydencjonalne o wysokim standardzie, zaczątki i to bardzo nieśmiałe osiedli wypoczynkowych oraz pierwsze próby wykorzystywania osadmictwa wiejskiego dla celów letniskowych. Dla wypoczynku wykorzystuje się głównie tereny leśne, najczęściej lasów sosnowych porastających pagórki i wydmy podłódzkie, a także cieki wodne czy stawy, sztucznie spiętrzone na okolicznych rzekach.

\section{OSADNICTWO WYPOCZYNKOWE OKOLIC ŁODZI W DWUDZIESTOLECIU MIĘDZYWOJENNYM}

Odzyskanie przez Polskę niepodległości w 1918 r. Łódź okupiła znacznymi stratami gospodarczymi, które nie przyniosły jednak większych zmian w strukturze społecznej tego miasta (A. G in s bert 1962).

Dominującą, w sensie administracyjno-militarnym, rolę utraciła $i$ tak nieliczna tu grupa ludności rosyjskiej, na niezmienionych pozycjach ekonomicznych, choć $w$ innych proporcjach ilościowych (udział ludności niemieckiej w Łodzi w 1921 r. kształtował się na poziomie $7 \%$ ), pozostali natomiast Niemcy i Żydzi. Nieznacznie rozwinął się $w$ tym okresie system komunikacji szynowej. Łódź otrzymała w 1925 r. połączenie kolejowe z Kutnem oraz tramwajowe z Ozorkowem w $1921 \mathrm{r}$. i Lutomierskiem w $1924 \mathrm{r}$. Wyraźnej poprawie, zwłaszcza w latach trzydziestych uległ natomiast ogólny poziom życia mieszkańców Łodzi, co znalazło odbicie w zwiększonym zapotrzebowaniu na wypoczynek poza miejscem stałego zamieszkania.

Realizacji tych potrzeb sprzyjała ustawa o reformie rolnej z 28 grudnia 1925 r., która przewidywała m.in. pozostawienie w okręgach przemysłowych i podmiejskich majątków nie przekraczających 60 ha. Usta- 
wa ta znacznie przyspieszyła parcelację majątków ziemskich w okolicach Łodzi i umożliwiła powstanie osadnictwa wypoczynkowego.

W omawianym okresie obserwuje się nadal powstawanie nielicznych rezydencji podmiejskich, głównie bogatych przemysłowców (np. w Kęblinach czy Grotnikach). Postępuje także rozwój funkcji wypoczynkowej w miejscowościach, w których już przed I wojną światową zaczęły powstawać obiekty letniskowe (Arturówek, Rogi, Ruda Pabianicka) lub zaczęto wynajmować kwatery (Głowno, Wiśniowa Góra), ale przede wszystkim z inicjatywy osób indywidualnych, a także władz miejskich Łodzi, powstają $w$ okolicach miasta oryginalne osiedla letniskowe: Kolumna, Sokolniki, Tuszyn Las i Grotniki.

Dobre warunki naturalne, a zwłaszcza węzeł hydrograficzny rzek: Mrogi, Mrożycy i Brzuśni, które przecinają tu utwory czwartorzędowe pochodzenia lodowcowego, porośnięte suchym lasem, spowodowaly iż okolice miasta Głowna ( $30 \mathrm{~km}$ od Łodzi) stały się $w$ tym okresie ulubionym miejscem wypoczynku mieszkańców Łodzi.

Walory te wzmocniła jeszcze linia kolejowa, która od 1903 r. zapiewniła sprawne połączenie komunikacyjne Głowna z Łodzią i Warszawą,

Najstarsza dzielnica letniskowa Głowna, Warchołów, powstała jeszcze przed I wojną światową. Pierwotnie wynajmowano tu kwatery u chłopów, potem pobudowano domy letniskowe. Prawdziwy jednak rozwój osadnictwa letniskowego nastąpił w Głownie po I wojnie światowej. Najwcześniej powstała dzielnica letniskowa o nazwie Swoboda, usytuowana nad rzeką Mrogą, potem tzw. Letniska Warchołów, położone po obu stronach toru kolejowego. Polacy wykupili tu tereny piaszczyste od rodziny Danieleckich, Żydzi tereny leśne położone za torem kolejowym należące do majątku A. Komorowskiej. Następnie teren ten został zabudowany willami letniskowymi oraz domkami drewnianymi z werandami. Rola i znaczenie Warchołowa jako obszaru wypoczynkowego została zaznaczona $w$ oficjalnych dokumentach $\mathrm{z}$ tego okresu Dziennik Urzędowy woj. łódzkiego z dnia 25 maja 1926 r., podając wykaz kąpielisk i letnisk w województwie, wśród innych wymieniał również Warchołów.

Największy jednak przełom w rozwoju funkcji letniskowej nastąpił w Głownie po wprowadzeniu ustawy o reformie rolnej (1925 r.). Spowodowała ona na tym terenie wyprzedaż i parcelację majątków ziemskich i powstanie nowych dzielnic letniskowych. W tym to okresie na gruntach majątku Lemańskich powstała dzielnica o nazwie Otwock, a z części majątku Komorowskiej dzielnica Nowe Zakopan.

Jedyną osobą wśród właścicieli majątków położonych w okolicach Głowna, która świadomie przeznaczyła parcelowany teren na letnisko był hrabia Kazimierz Rzewuski. Rozparcelował on obszar leśny, dzieląc 
go na 127 działek (dzielnica Moczydła), z jednoczesnym zastrzeżeniem w księdze wieczystej, wg którego nowym właścicielom działek nie wolno było wycinać więcej niż $1 / 3$ część drzewostanu, pozostawiając $2 / 3$ części nietknięte $w$ celu zachowania letniskowego charakteru miejscowości. Wiedług tych ustaleń budynki mogły być wznoszone w odległości $5 \mathrm{~m}$ od brzegu ulicy. Nie wolno było w ciągu 15 lat (licząc od 7 marca 1930 r.) przeprowadzić przez działkę drogi publicznej ani też budować i wznosić gmachów fabrycznych czy też jakichkolwiek składów o charakterze przemysłowym. Nie wolno było również dzielić działek ziemi na mniejsze parcele.

Ten intensywny rozkwit funkcji letniskowej w Głownie był związany $\mathrm{z}$ postępującym rozwojem komunikacji ułatwiającej dostęp do tego miasta. Obok połączenia kolejowego z dniem 1 stycznia $1926 \mathrm{r}$. zostaje uruchomiona komunikacja autobusowa na trasie Łódź-Zgierz-Głowno. W sezonie letnim 1936 r. kolej uruchomiła również tzw. zielone linie. Niezależnie od tej masowej komunikacji pomiędzy Łodzią i Głownem nadal funkcjonował $w$ okresie międzywojennym transport konny. Dotyczyło to zwłaszcza początku i końca sezonu letniego, kiedy to furmankami osobowo-transportowymi przewożono do Głowna na letnisko całe rodziny, często lącznie $\mathrm{z}$ meblami i niezbędnym do bytowania sprzętem.

Pierwszymi nabywcami działek letniskowych w Głownie byli głównie Żydzi łódzcy i brzezińscy, ale także mieszkańcy Warszawy, Głowna i innych miejscowości. Powstałe w późniejszym okresie osiedle Nowe Zakopane i Otwock zagospodarowali głównie Żydzi z Łodzi i innych dużych miast przemysłowych.

Głowno w okresie międzywojennym pełniło w sezonie letnim funkcję wypoczynkową i to nie tylko wypoczynku indywidualnego czy rodzinnego. Począwszy od 1930 r. organizowano tu również, korzystając z budynku miejscowej szkoły, kolonie letnie dla dzieci łódzkich. Miarą tej funkcji może być również charakter zabudowy miasta. W 1938 r. na 811 budynków mieszkalnych, jakie zarejestrowano w Głownie i najbliższej okolicy, $477(59 \%)$ pełniło w różnym zakresie funkcję wypoczynkową. Wśród nich było 5 pensjonatów, 38 willi letniskowych oraz 90 domów letniskowych. W pozostałych domach wynajmowano kwatery dla letników (H. S z y m c z a k 1982).

Drugim przykładem miejscowości podłódzkiej, w kiórej zalążki funkcji letniskowej istniały jeszcze przed I wojną światową, ale jej rozwój nastąpił w okresie międzywojennym, jest wieś Wiśniowa Góra.

Głównym walorem wypoczynkowym tej miejscowości były lasy sosnowe, pokrywające pleistocen̉ską wysoczyznę zbudowaną z piasków i żwirów wodno-lodowcowych. Te zdrowe, jak powszechnie uważano, 
tereny, położone zaledwie w odległości $14 \mathrm{~km}$ od Łodzi, z możliwością dojazdu kolieją (dojście $3 \mathrm{~km}$ od stacji Bedoń), stały się miejsciem ekspansji funkcji letniskowiej w okresie międzywojennym.

Masowa parcelacja terenów. Wiśniowej Góry nastąpiła po 1930 r., kiedy to został zniesiony zakaz rozdrabniania, sprzedaży lub dzierżawy parcel zakupionych od właścicieli Bedonia. Ziemię kupowali tu przeważnie Żydzi, którzy rozpoczęli w latach trzydziestych budową domów letniskowych na dużą skalę. W okresie tym powstało $m$. in. 9 dużych pensjonatów oraz ośrodek wypoczynkowy $\mathrm{z}$ basenem kąpielowym, a także kilkadziesiąt innych budynków letniskowych. O rozwoju Wiśniowej Góry w okresie międzywojennym może świadczyć fakt, iż z ogólnej liczby 663 budynków, jakie istniały w tej miejscowości w 1980 r., aż $564(85 \%)$ powstało w okresie międzywojennym (G. W i lc z a k 1982).

W omawianym okresie Wiśniowa Góra staje się miejscowością wypoczynku letniskowego dla średnio zamożnych mieszkańców Łodzi, głównie pochodzenia żydowskiego. Pobyt na letnisku w tej miejscowości był relatywnie tariszy i łatwiej dostępny niż w innych miejscowościach podłódzkich, na co składało się głównie brak w pobliżu wód, nadających się do kąpieli oraz bliskość Łodzi. Umożliwiło to wypoczywającym w Wiśniowej Górze częsty kontakt ze stałym miejscem zamieszkania (z Łodzi do Wiśniowej Góry kursował autobus, a liczne dorożki ułatwiały dojazd do stacji kolejowej w Bedoniu), a nawet nieprzerywanie pracy w sezonie przez pracujących członków rodziny.

O znaczeniu Wiśniowej Góry jako miejscowości letniskowej w okresie międzywojiennym może świadczyć fakt, iż w końcu lat trzydziestych wypoczywało tu po ok. 5000 osób (G. W i l c z a k 1982).

Zupełnie inną genezę, a i charakter ma osadnictwo wypoczynkowe powstałe w omawianym okresie na tzw. "surowym korzeniu" w sposób planowy i uporządkowany. Dotyczy to w okolicach Łodzi czterech miejscowości: Miasta-Lasu Kolumny, Miasta-Ogrodu Sokolnik, Tuszyn Lasu i w mniejszym stopniu Grotnik. Wnikliwą analizę jednego z tych osiedli, Kolumny, przeprowadził A. Matczak (w druku). Warto tu jednak zwrócić uwagę na pewne cechy wspólne dla wszystkich w ten sposób i w tym okresie powstających miejscowości wypoczynkowych.

Wszystkie one powstały na terenach leśnych, głównie lasów sosnowych o suchym, piaszczystym podłożu. Ich powstanie poprzedziły parcelacje terenów leśnych i częściowo rolniczych, które miały miejsce w konicu lat dwudziestych i na początku trzydziestych naszego wieku.

Powstałe $w$ ten sposób miejscowości wypoczynkowe były zakładane w sposób planowy i posiadały układy przestrzenne czytelne w swojej sieci ulic i placów do chwili obrecnej. Koncepcja urbanistyczna tych 
miejscowości nazywana przez A. Matc z a ka (1984 r.) „układem parkowym, nawiązywała do modnej wówczas w Polsce idei E. Howarda "miast-ogrodów".

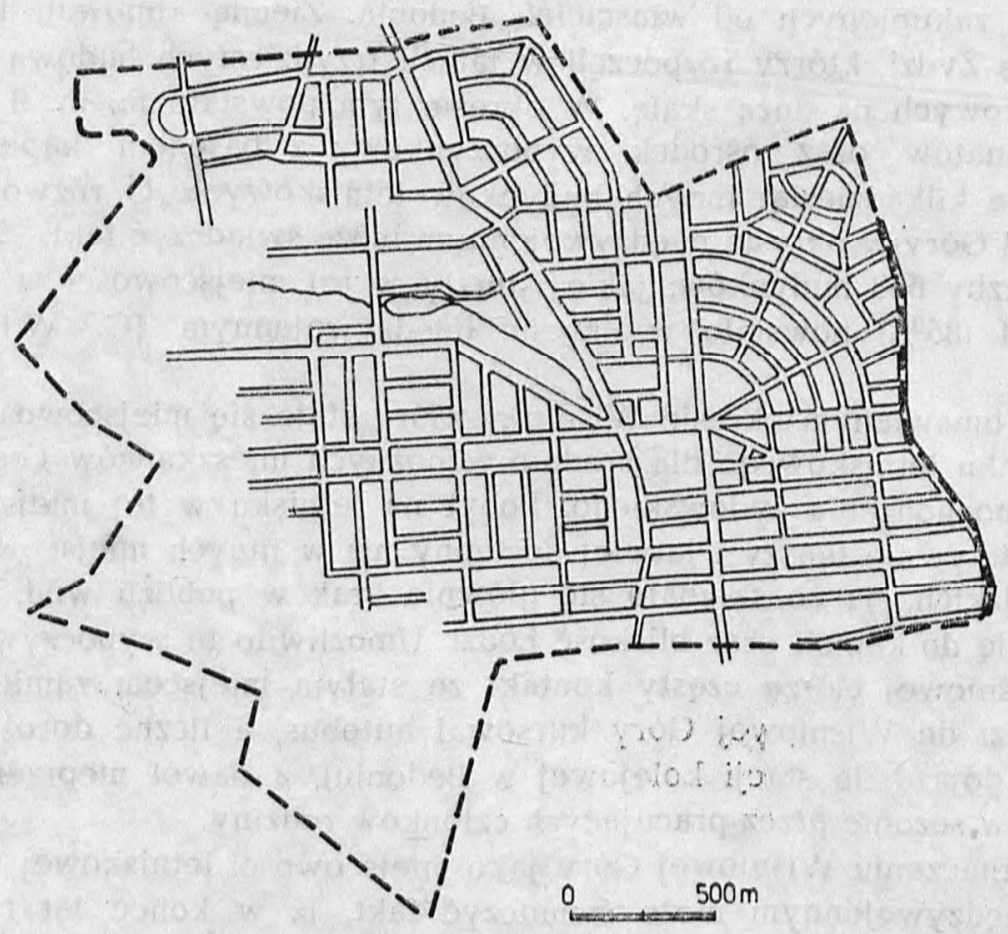

Rys. 1. Układ przestrzenny Miasta-Ogrodu Sokolniki

Fig. 1. Disposition spatiale de la ville-jandin de Sokolniki

Powstałe na "surowym korzeniu" w okresie międzywojennym miejscowości wypoczynkowe lokowano w niedalekiej odległości od Łodzi $(20-30 \mathrm{~km})$, wzdłuż istniejących szlaków komunikacji szynowej. Kolumna i Grotniki powstały przy linii kolejowej, Sokolniki i Tuszyn Las w zasięgu tramwaju dojazdowego. Nabywcami działek w powstających osiedlach letniskowych byli pierwotnie ludzie zamożni, przemysłowcy, kupcy, bankierzy itp., głównie mieszkający w Łodzi, choć w zależności od położenia osiedla partycypowali $w$ tych zakupach bogaci mieszkańcy innych miast. Na przykład w 1927 r. 20,4\% działek w Kolumnie należało do mieszkańców Pabianic (M. K u bi a k 1982), a wśród posiadających działki w Sokolnikach i Grotnikach była też część mieszkańców Zgierza. Pierwotnie działki kupowali przedstawiciele wszystkich 
grup narodowościowych, później w miarę rozwijającej się spekulacji ziemią znaczniejsza ich część znalazła się w rękach właścicieli pochodzenia żydowskiego.

Osiedla powstające planowo w zakresie układu przestrzennego, odznaczały się dużym zróżnicowaniem fizjonomii zabudowy. Budowano tu pensjonaty czynne cały rok i przynoszące znaczny dochód swym właścicielom, duże domy lub wille letnie przeznaczone dla rodziny i znajomych oraz domy letniskowie o różnorodnej architekturze i standardzie.

Osiedla te, staraniem ich organizatorów, właścicieli czy mieszkańców, były wyposażone w niezbędne urządzenia usługowe, a zwłaszcza sklepy, obiekty gastronomiczne, sportowe i rozrywkowe.

Porównując liczbę stałych mieszkańców tych osiedli w stosunku do ilości wypoczywających w nich osób oraz sezonowość pobytów można stwierdzić, iż były to typowe w swej funkcji, urbanistyce i fizjonomii osiedla wypoczynkowe.

Podobnie jak i w pierwszym $\mathrm{z}$ omawianych okresów (przed I wojną światową), tak i w 20-leciu międzywojennym, najliczniejsza i najbiedniejsza część mieszkańców Łodzi swój wolny od zajęć czas spędzała na nielicznych tererach zielonych miasta lub $w$ najbliższym jego otoczeniu.

Nadal odwiedzano Eagiewniki, Młynek, Stawy Stefańskiego czy park Źródliska. W okresie tym miejscem wypoczynku stał się także zorganinizowany w latach 1924-1931 Park Ludowy na Zdrowiu, a także park 3 Maja (1919 r.).

Okres międzywojenny odznacza się również powstawaniem w okolicach Łodzi szpitali o funkcjach sanatoryjnych, specjalizujących się głównie w leczeniu chorób płuc. W 1920 r. zorganizowano sanatorium dla dzieci w Łagiewnikach, a w latach 1925-1926 wybudowano szpital-sanatorium w Tuszynku. Z nieco wcześniejszego okresu pochodzi inny szpital gruźliczy, który wybudowano w południowej, zalesionej wówczas części Chojen w 1916 r. (obecnie znajduje się on przy ul. Kosynierów Gdyńskich).

Oceniając rozwój osadnictwa wypoczynkowego w okolicach Łodzi w okresie międzywojennym należy podkreślić jego dynamikę. Zainteresowanie wypoczynkiem poza miejscem zamieszkania tej dużej, liczącej wówczas ponad 0,6 mln mieszkańców aglomeracji miejskiej, gwałtownie w tym okresie wzrosło, a próbą zaspokojenia tego zapotrzebowania był zarówno rozwój i przekształcenia wcześniej istniejących osiedli, wsi czy miast, w których funkcja letniskowa współwystępowała $\mathrm{z}$ inną (Głowno, Wiśniowa Góra), jak również w powstaniu zupełnie nowych, oryginalnych osiedli o wyłącznej funkcji letniskowej. W ten sposób, w ukształtowaną wcześniej sieć osadniczą okolic Łodzi, w okresie mię- 
dzywojennym wtargnął po raz pierwszy nowy element - osadnictwo wypoczynkowe.

\section{OSADNICTWO WYPOCZYNKOWE OKOLIC ŁODZI PO II WOJNIE SWIATOWEJ}

II wojna światowa i okupacja hitlerowska wyeliminowały z życia mieszkańców Łodzi pojęcie wypoczynku poza miejscem stałego zamieszkania. Konsekwencje tego straszliwego okresu, wyrażające się m.in. zagładą ludności żydowskiej, ucieczką mieszkańców pochodzenia niemieckiego i ogólnym ubóstwem pozostałych przy życiu łodzian, oddaliły w czasie możliwość powrotu do wypoczynku w strefie podmiejskiej. Ważnym czynnikiem kształtującym nową sytuację stała się również zmiana ustroju społeczno-politycznego, jaka nastąpiła w Polsce po II wojnie światowej.

Powstałe $w$ okresie międzywojennym osiedla letniskowe zamieniono po wyzwoleniu na osiedla mieszkaniowe, kwaterując w nich napływających do Łodzi osadników. Przeznaczano na ten cel głównie poniemieckie i pożydowskie wille i domy letniskowe, a także niektóre pensjonaty, dostosowując je pospiesznie w sposób prymitywny i tymczasowy do nowej funkcji. Część większych obiektów pensjonatowych przekazano $\mathrm{w}$ tym czasie dużym zakładom pracy Łodzi $\mathrm{z}$ przeznaczeniem na ośrodki kolonijne i wypoczynkowe. W ten sposób realizowano zasady nowego ustroju, umożliwiając wyjazd wakacyjny poza miasto wielu tysiącom łódzkich dzieci.

Zmiana funkcji, choć w mniejszym zakresie, objęła również podmiejskie rezydencje fabrykanckie, które wraz z upaństwowieniem przemysłu przeszły pod nowy zarząd, stając się najczęściej zakładowymi ośrodkami kolonijnymi (np. ośrodek w Kęblinach, Głownie i inne).

Tak więc $w$ pierwszych latach po wyzwoleniu nastąpiło ograniczenie, a w niektórych przypadkach nawet zanik funkcji wypoczynkowej w dawnych osiedlach letniskowych strefy podmiejskiej Łodzi. Ze względu na rodzaj istniejącej zabudowy Wiśniowa Góra, Kolumna i Grotniki, obok funkcji mieszkaniowej, stały się w tym czasie dużymi ośrodkami kolonijnymi. W znacznie mniejszym zakresie funkcję wypoczynkową pełniły w tych latach Głowno i Sokolniki, a Tuszyn Las niemal w całości stał się osiedlem mieszkaniowym.

Można zaryzykować stwierdzenie iż w sposób wymuszony, wynikający z trudnej sytuacji zniszczonego kraju, osiedla letniskowe strefy podmiejskiej Łodzi przeszły w tym okresie proces intensywnej urbanizacji, wyrażający się główrie w zasiedlaniu ich stałymi mieszkańcami. 
Począwszy od połowy lat sześćdziesiątych obserwuje się w okolicach Łodzi bardziej wzmożone zainteresowanie posiadaniem działki czy własnego domku letniskowego. Przyczyn tego stanu należy upatrywać we względnym wzroście zamożności społeczeństwa miejskiego, rozwoju indywidualnych środków komunikacji, a także w starzeniu i wyludnianiu się wsi podmiejskich.

W ten sposób powstają nowe warunki wyrażającie się $\mathrm{z}$ jednej strony - popytem na wypoczynek poza miastem mieszkańców Łodzi, z drugiej zaś - swoistego rodzaju podażą terenów podmiejskich, która powstaje w sposób często nielegalny, a wyraża się dzieleniem podupadających gospodarstw chłopskich na działki letniskowe. Powstaje w okolicach Łodzi sytuacja wyjątkowa, w której nie walory naturalne decydują o zaǩkupie działki letniskowej, ale możliwość jej nabycia, często nawet w znacznym oddaleniu od kompleksu lasów czy zbiorników wodnych.

W takich warunkach dochodzi do najbardziej dynamicznego, w dotychczasowej historii strefy podmiejskiej Łodzi, rozwoju osadnictwa wypoczynkowego. Powstaje ono wokół starych, międzywojennych jąder osadniczych, powodując ich rozbudowę (Sokolniki, Grotniki) bądź tworząc nowe samodzielne jednostki, jak ma to miejsce wokół Kolumny czy Tuszyn Lasu. Przede wszystkim, w okresie tym powstają jednak nowe osady letniskowe, które lokują się na rozparcelowywanych gruntach chłopskich. Najczęściej nie tworzą one nowych założeń urbanistycznych, ale zmieniają charakter użytkowania zachowanych $\mathrm{w}$ swej formie przestrzennej rozłogów wiejskich, podzielonych na różnej wielkości działki letniskowe.

O skali i natężeniu tego zjawiska może świadczyć fakt, iż jak podaje A. Matczak (1982), jeszcze w 1966 r. w strefie podmiejskiej Łodzi było 2840 działek letniskowych, w 1970 r. - 3474, ale już w 1979 r. 6168 działek. Zjawisko to potwierdziają również wyniki (bardzo niedoskonałego w tym zakresie) Narodowego Spisu Powszechnego z 1978 r. Według tych informacji w 1978 r. istniało na terenie strefy podmiejskiej Łodzi 2991 domów letniskowych, z czego 8,7\% wybudowanych było przed 1945 r., 53,7\% w latach 1945-1970, a pozostałe $37,6 \%$ w ostatnim okresie, tzn. w latach $1971-1978$.

Spontanicznie powstające nowe osadnictwo letniskowe objęło w tym czasie wiele wsi podłódzkich położonych zarówno wzdłuż tradycyjnych ciągów komunikacji szynowej, jak również wzdłuż wielu dróg kołowych i to często o lokalnym znaczeniu. Przykładem takiego osadnictwa ukształtowanego w całości $w$ omawianym okresie może być wieś Janówka położona w gminie Andrespol.

Wieś ta o kształcie typowej ulicówki jest położona w odległości 
ok. $17 \mathrm{~km}$ od Łodzi przy linii kolejowej Łódź-Koluszki. Główna oś tej wsi przebiega niemal prostopadle do linii kolejowej, z którą przecina się w Justynowie i równolegle ( $w$ odległości $300-600 \mathrm{~m}$ ) do dużego kompleksu lasów gałkowskich. Proces przemian tej wsi rozpocząl się tu w latach 1960 - 1965 i objął niewielki fragment przylegający bezpośrednio do linii kolejowej. W latach 1965-1970 kupowano działki letniskowe już w części środkowej wsi, a po 1970 r. wykupiono tereny położone w odległości ok. $2 \mathrm{~km}$ od stacji PKP.

W 1979 r. na 366 działek budowlanych znajdujących się na terenie wsi, 235 pełniło funkcje wypoczynkowe, przy czym $190 \mathrm{z}$ nich posiadało zabudowę letniskową (J. N a polsk a 1981). Większość działek letniskowych powstała w Janówce na skutek parcelacji gospodarstw chłopskich. Wśród obecnych właścicieli $7 \%$ kupiło działki z ogłoszenia w prasie, $16 \%$ nabyło je od krewnych, $58 \%$ dowiedziało się o możliwości zakupu przez znajomych, a pozostali w poszukiwaniu działki przyjechali do Janówki i nawiązali sami kontakt z gospodarzami.

Układ przestrzenny tego nowego osiedla letniskowego bardzo odbiega od układów osiedli powstających w okresie międzywojennym. Powstał on na skutek podzielenia wąskich pól chłopskich, ułożonych prostopadle do głównej osi wsi, na działki letniskowe o wymiarach od 500 do $1500 \mathrm{~m}^{2}$. Podział ten nie naruszył układu dawnych pól i siedlisk wiejskich, rozdrobnił je jednak i zmienił w sposób zasadniczy ich użytkowanie.

Właścicielami działek letniskowych w Janówce są głównie mieszkańcy Łodzi, z których ok. 65\% w okresie prowadzonych badań (1979 r.) było w wieku powyżej 50 lat. W grupie tej aż $28 \%$ stanowią emeryci i renciści. Interesującym jest fakt, iż ok. $40 \%$ właścicieli działek letniskowych w Janówce planuje budowę tam stałego domu i zamieszkania na wsi. Swiadczy to, że funkcja letniskowa tego osiedla ma charakter przejściowy.

Szczegółowe badania przeprowadzone przez A. Matczaka (1985) w strefie podmiejskiej Łodzi wykazały, iż w 1979 r. 282 sołectwa i 10 miast tej strefy posiadało $\mathrm{w}$ różnym stopniu rozwiniętą funkcję wypoczynkową. Z tej liczby 54 sołectwa uznać można było jako posiadające funkcję wypoczynkową rozwiniętą w stopniu średnim lub silnie, a 9 sołectw posiadało tę funkcję w pełni ukształtowaną. Do tych ostatnich zaliczono dwa osiedla, które powstały jako letniskowe w okresie międzywojennym i utrzymały nadal ten charakter (Grotniki i Sokolniki) oraz siediem sołectw, które ukształtowały tę funkcię w ostatnim okresie (Ustronie, Swędów, Justynów, Janówka, Żabiczki, Wrząca, Nowy Swiat). Interesująco $\mathrm{w}$ tej klasyfikacji wypadły pozostałe osiedla letniskowe 


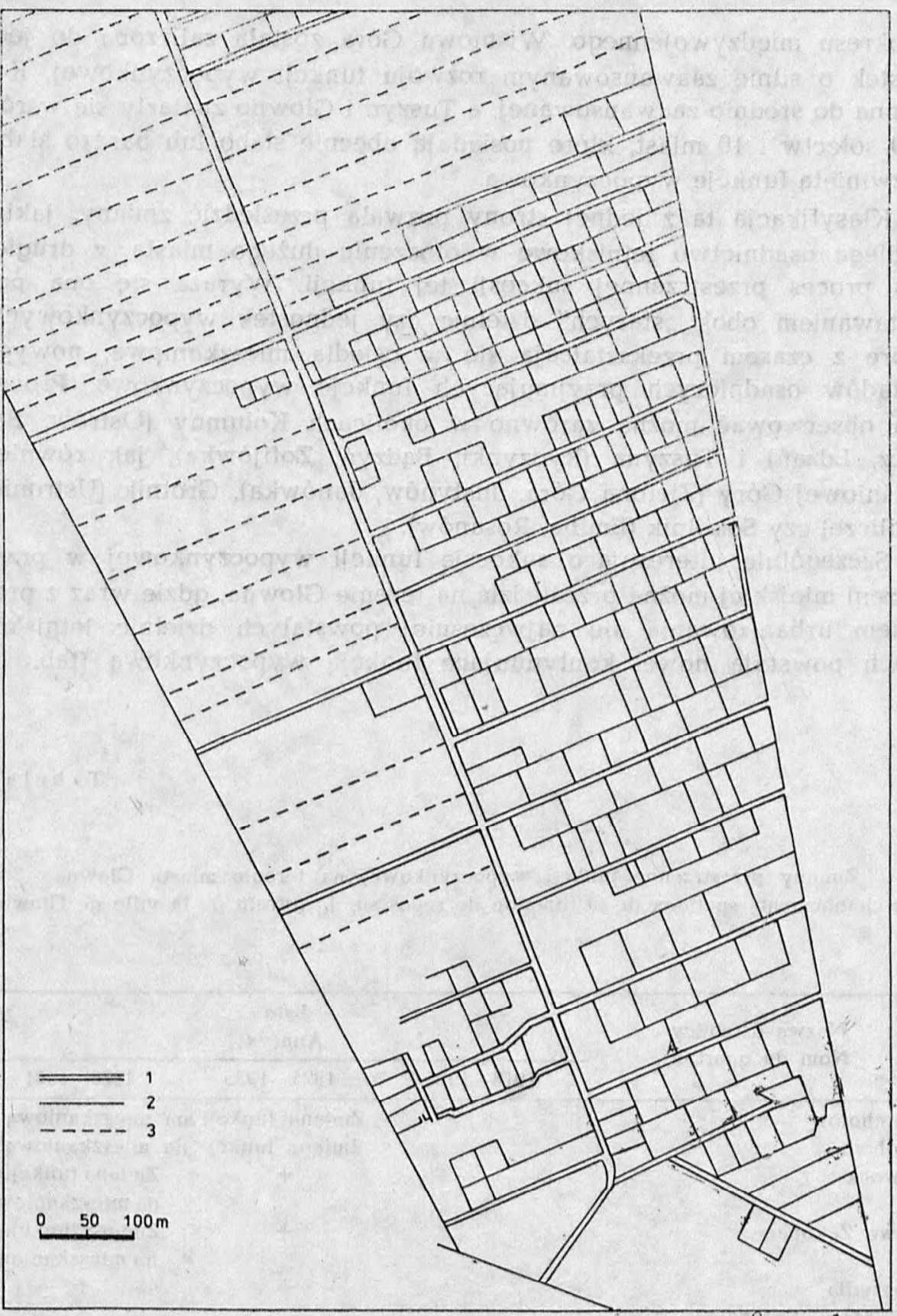

Rys. 2. Układ przestrzenny wsi Janówka

1 - drogi, 2 - granice działek rekreacyjnych, 3 - granice pól

Fig. 2. Disposition spatiale du village Janówka

1 - chemins, 2 - limites des parcelles de récréation, 3 - limites des champs 
z okresu międzywojennego. Wiśniowa Góra została zaliczona do jednostek o silnie zaawansowanym rozwoju funkcji wypoczynkowej, Kolumna do średnio zaawansowanej, a Tuszyn i Głowno znalazły się wśród 219 sołectw i 10 miast, które posiadają obecnie słabo lub bardzo słabo rozwiniętą funkcję wypoczynkową.

Klasyfikacja ta z jednej strony pozwala prześledzić zmiany, jakim podlega osadnictwo letniskowe $w$ otoczeniu dużego miasta, $z$ drugiej zaś proces przestrzennej sukcesji tej funkcji. Wyraża się ona powstawaniem obok "starych" dzielnic czy jednostek wypoczynkowych, które $\mathrm{z}$ czasem przekształcają się $\mathrm{w}$ osiedla mieszkaniowe, nowych układów osadniczych przyjmujących funkcje wypoczynkowe. Proces ten obserwować można zarówno w okolicach Kolumny (Ostrów, Barycz, Ldzań) i Tuszyna (Rydzynki, Bądzyń, Zofijówka), jak również Wiśniowej Góry (Zielona Góra, Justynów, Janówka), Grotnik (Ustronie, Jedlicze) czy Sokolnik (Emilia, Rosanów).

Szczególnie interesująco sukcesję funkcji wypoczynkowej w przestrzeni miejskiej można prześledzić na terenie Głowna, gdzie wraz z procesem urbanizowania się najwcześniej powstałych dzielnic letniskowych powstają nowie, kontynuujące funkcję wypoczynkową (tab, 1).

$\mathrm{T}$ a b e l a 1

Zmiany przestrzenne funkcji wypoczynkowej na terenie miasta Głowna Les changements spatiaux de la fonction de repos sur $l_{\mathrm{e}}$ ternain de la ville de Głowno

\begin{tabular}{|c|c|c|c|}
\hline \multirow{2}{*}{$\begin{array}{l}\text { Nazwa dzielnicy } \\
\text { Nom du quartier }\end{array}$} & & $\begin{array}{l}\text { Lata } \\
\text { Années }\end{array}$ & \\
\hline & $1918-1925$ & $1925-1935$ & $1970-1981$ \\
\hline Warchołów & + & Zmiana funkcji na & a mieszkaniową \\
\hline Swoboda & + & Zmiana funkcji no & a mieszkaniową \\
\hline Otwock & & + & Zmiana funkcji \\
\hline Nowe Zakopane & & + & \\
\hline Moczydła & & + & $\begin{array}{c}\text { na mieszkanıową } \\
+\end{array}$ \\
\hline Kol. Stary Warchołów & & & + \\
\hline Kol. Zabrzeźnia & & & + \\
\hline
\end{tabular}

+ Występowanie funkoji wypoczynkowej. 


\section{WNIOSKI}

Przedstawiony szkic powstania i rozwoju osadnictwa wypoczynkowiego w okolicach Łodzi umożliwia sformułowanie ogólniejszych wniosków, prawidłowości i postulatów badawczych.

Badania analityczne pozwalają stwierdzić, iż powstanie i rozwój osadnictwa wypoczynkowego $w$ otoczeniu Łodzi było wypadkową między zapotrzebowaniem mieszkańców miasta a możliwościami jego zaspokojenia przez najbliższy obszar. Zapotrzebowanie to wynikało $\mathrm{z}$ trudnych warunków życia w wielkomiejskim środowisku przemysłowym, wzrastającej świadomości spolecznej, a także różnych zmieniających się zasobów materialnych. Możliwości zaspokojenia tych potrzeb przez obszar otaczający Łódź były warunkowane głównie rozwojem komunikacji i dostępnością prawną terenu. Śodowisko naturalne odegrało tu rolę drugorzędną, choć jego wpływ na powstanie najstarszych osiedli wypoczynkowych jest wyraźny (tereny o suchym, piaszczystym podłożu, pokryte lasem iglastym w pobliżu rzeki).

Zarówno czynniki warunkujące popyt jak i te, które zabezpieczały podaż wypoczynku wystąpiły w przypadku Łodzi ze znacznym opóźnieniem $w$ stosunku do innych dużych miast Polski, co wynika $z$ genezy i procesu rozwoju samej Łodzi. Znalazło to odzwierciedlenie we wciąż jeszcze słabym na tym obszarze rozwoju jednostek osadniczych pełniących stricte funkcje wypoczynkowe. Występują tu współcześnie tylko dwie greneracje osadnictwa wypoczynkowego. Pierwszą tworzą nieliczne, ale w pełni wykształcone osiedla letniskowe powstałe w okresie międzywojennym, drugą znacznie liczniejsze, ale gorzej zorganizowane osadnictwo powstające współcześnie, głównie w wyniku podziałów gospodarstw chłopskich.

W świetle obserwacji łódzkich, zaryzykować można hipotezę, i̇̇ osadnictwo letniskowe $\mathrm{w}$ okolicach dużych miast było i jest etapem w procesie urbanizacji terenów podmiejskich. Czesto poprzedza ono ten proces, ale wyznacza również jego kierunek przestrzenny, a w konsekwencji przyszły kierunek rozwoju miasta czy aglomeracji.

Prowadzone badania wykazały także występowanie w otoczeniu Łodzi sukcesji przestrzennej funkcji wypoczynkowej. Powstanie na poczatku XX w. oraz w okresie międzywojennym pierwszych osiedli letniskowych wokół Łodzi zadecydowało o podstawowych kierunkach rozwoju osadnictwa wypoczynkoweco na tym obszarze w następnych dziesięcioleciach. Dzieje się tak pomimo przemian, jakim uleqły te pierwotne jądra osadnictwa wypoczynkowego, tracąc nawet w kilku przypadkach pierwotne funkcje. Jak wykazały badania, nie stanowi 


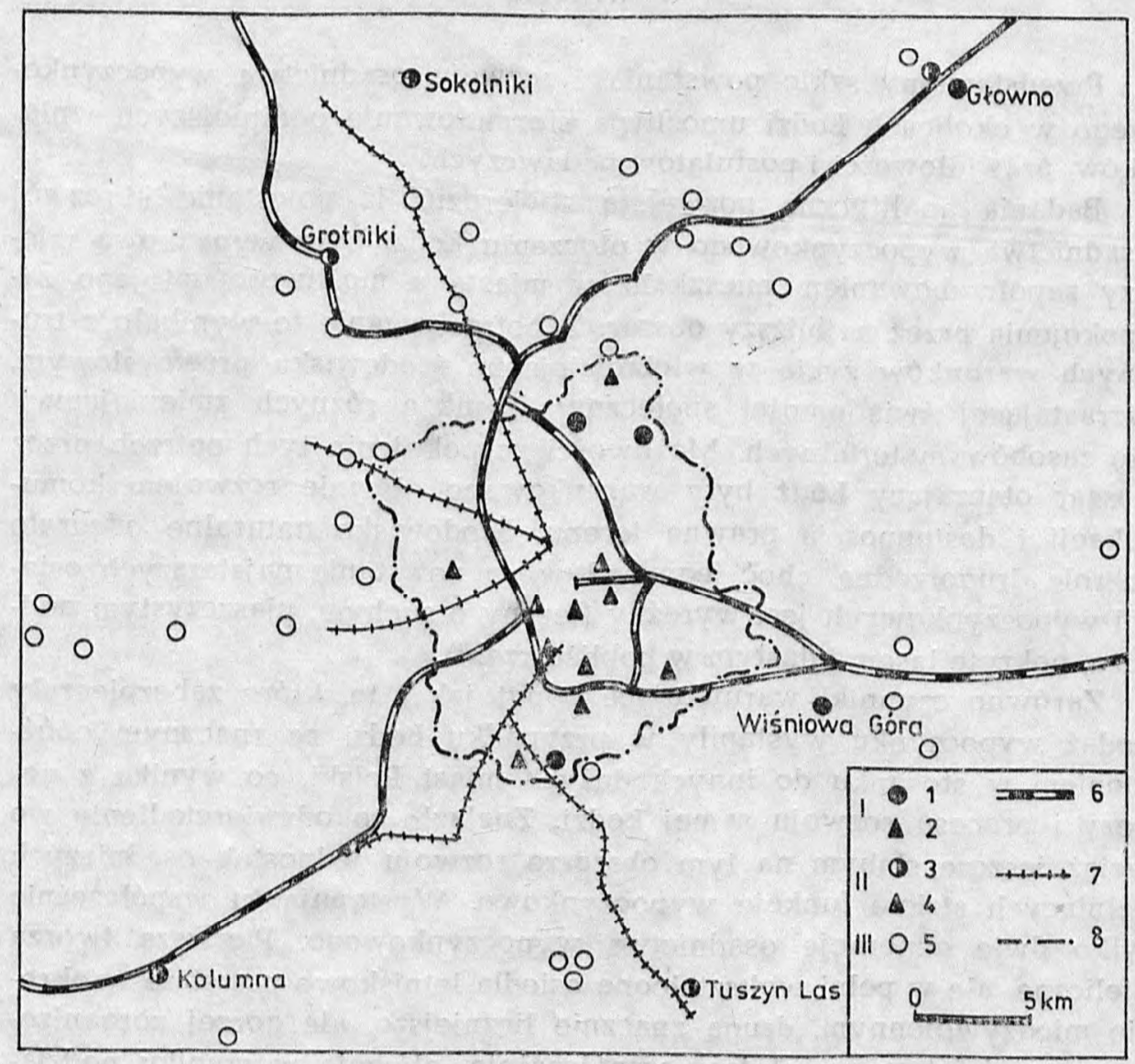

Rys. 3. Rozwój osadnictwa wypoczynkowego okolic Łodzi na tle sieci komunikacji szynowej

I etap: 1 - osiedla wypoczynkowe powstałe przed I wojną światową, 2 - miejsca wypoczynku ludności kodzi przed I wojną światową; II etap: 3 - osiedla wypoczynkowe powstałe w okresie dwuáziestolecia międzywojennego, 4 - miejsca wypoczynku mieszkańców Łodzi powstałe w okresie dwudziestolecia międzywojennego; III etap: 5 - osiedla w których funkoja wypoczynkowa rozwinęla się w okresie po II wojnie światowej, 6 - koleje, 7 - tramwaje podmiejskie, 8 - granice administracyjne Łodzi $w 1986 \mathrm{r}$.

Fig. 3. Développement de la colonisation de repos dans les environs de Łódź sur le fond du résean ferroviaire

I ère étape: 1 colonies de repos fondées avant la 1 ère querre mondiale, 2 - lieux de repos des habitants de Édź avant la 1 ère guerre mondiale; II ème étape, 3 - colorín de repos fondées dans la période d'entre deux guerres, 4 - lieux de repos des habitants de É́dĺ̀ dans la périote d'entre deux guerres; III ème etape: 5 - colonies dont la fonction de repos s'est développée après la II ème guerre mondiale; 6 - chemins de fer, 7 - tramways suburbains, 8 - timites administratives de Édź en 1986 
to jednak przeszkody $\mathrm{w}$ powstawaniu nowych osiedli letniskowych, które otaczając stare jądra osadnicze rozwijają się lub kultywują funkcje wypoczynkowe tych obszarów.

Przeprowadzona analiza pozwala również na sformułowanie dalszych postulatów badawczych, których realizacja powinna umożliwić wykrycie i lepsze zrozumienie zachodzących procesów, jak również wskazać istniejące prawidłowości. Dalsze badania nad osadnictwem wypoczynkowym w otoczeniu dużych miast winny koncentrować się na:

- wykryciu i określeniu związków, zależności i prawidłowości, jakie zachodzą pomiędzy osadnictwem wypoczynkowym a procesami urbanizacji w strefach podmiejskich dużych miast;

- wyjaśnieniu przyczyn i następstw procesu sukcesji przestrzennej funkcji wypoczynkowej w sieci osadniczej obszarów podmiejskich;

- potwierdzeniu lub negacji powstawania, rozwoju i przemian podsystemów osadnictwa wypoczynkowego na obszarach podmiejskich dużych miast.

\section{PIŚMIENNICTWO}

Dylik J., 1971, Województwo ze stolicq bez antenatów. Geografia historyczna województwa łódzkiego, Łódzkie Towarzystwo Naukowe, Łódź.

Gi n s b e r t A., 1962, Łódź. Studium monograficzne, Łódź.

J a n c zak J., 1982, Ludność Łodzi przemysłowej 1820-1924, „Acta Universitatis Lodziensis", Folia historica 11.

Kopczyńska-Jaworska B., 1980, Zwyczaje $i$ obyczaje ludności Łodzi, [w:] Dzieje miasta, t. 1, Eódź.

Kubiak M., 1982, Rozwój funkcji wypoczynkowej Kolumny, maszynopis pracy magisterskiej wykonanej w Instytucie Geografii Ekonomicznej i Organizacji Przestrzeni UŁ.

Matczak A., 1982, Funkcja wypoczynkowa strefy podmiejskiej Łodzi, maszynopis pracy doktorskiej wykonanej w Zakładzie Geografii Miast i Turyzmu UŁ.

Matczak A., 1984, Próba wykorzystania analizy morfologicznej do określenia funkcji wypoczynkowej osiedli w strefie podmiejskiej Łodzi, „Problemy Turystyki", z. 2, s, 93-97.

Matczak A., 1985, Funkcja wypoczynkowa strefy podmiejskiej Eodzi, "Acta Universitatis Lodziensis", Folia geographica 5, s. 299-312.

Matczak A., 1986, Przyrodnicze podstawy organizacji wypoczynku w strefie podmiejskiej Łodzi, "Acta Universitatis Lodziensis", Turyzm 2, s, $25-45$.

Matczak A., 1987, Próba określenia funkcji wypoczynkowej osiedli podmiejskich na przykładzie Kolumny, "Acta Universitatis Lodziensis”, Turyzm 3.

$\mathrm{N}$ a polska J., 1981, Funkcja rekreacyjno-wypoczynkowa gminy Andrespol, maszynopis pracy magisterskiej wykonanej w Instytucie Geografii Ekonomicznej i Organizacji Przestrzeni UŁ.

Pietrzak A., 1973, Zmiany zalesienia terytorium województwa lódzkiego od okresu porozbiorowego do czasów obecnych, "Region Łódzki. Studia i materiały", t. 3 , s. $41-60$. 
St. raszewicz L., 1979, Indywidualność Łodzi na tle aglomeracji miejskich, "Zeszyty Naukowe UŁ", S. II, z. 21, s. 17-23.

Szymczak H., 1982, Funkcja turystyczna Glowna w zarysie historycznym, maszynopis pracy magisterskiej wykonanej w Instytucie Geografii Ekonomicznej i Organizacji przestrzeni UŁ.

Wilczak G., 1982, Funkcja wypoczynkowa osiedla Wiśniowa Góra, maszynopis pracy magisterskiej wykonanej w Instytucie Geografii Ekonomicznej i Organizacji Przestrzeni UŁ.

Doc. dr hab. Stanisław Liszewski

Wpłynęło:

Zakład Geografii Miast i Turyzmu

10 września $1986 \mathrm{r}$.

Instytutu Geografii Ekonomicznej

i Organizacji Przestrzeni

Uniwersytetu Łódzkiego

al. Kościuszki 21

90-418 Łódż

\section{RESUME}

Le travail a pour but l'explication de la génèse de la colonisation de repos aux environs de Łódź, l'identification et la fixation des étapes de celle-ci et les directions de cette forme de la colonisation Lódź, vu sa génèse, le train de son développement et la complexité des structures sociales de sa population, possède beaucoup de traits individuels, ce qui se réflète dans la colonisation de repos naissant aux environs de la ville.

Le développement de la colonisation de repos aux environs de.Łódź peut être divisé en 3 etapes: avant la lère guerre mondiale, entre les deux guerres, après la Ilème guerre mondiale

Avant la lère guerre mondiale apparaissent, sur le terrain examiné, les constructions résidentielles uniques fondées par de riches industriels de Łódź (Julianów, Łagiewniki) et les premières colonies de repos qui manquent de grâce (Arturówek, Rogi, Ruda Pabianicka), sibuées non loin du centre de la ville. Se font voir aussi les premières tentatives d'exploiter la colonisiation rurale en $v_{e}$ de séjour de repos.

A cette époque-là, on exploite pour le repos avant tout les terrains forestiers, le plus souvent les forêts de pin couvrant les monticules et les dunes dans les environs de Łódź, ssitués dans le voisinage des lignes de chemin de fer ou de tramways suburbains.

Dans les vingt années d'entre deux guerres, surtout dans la deuxième moitié de cette période, a lieu le développement dynamique de différentes formes de la colonisation de repos sir le terrain examiné. Les résidences suburbaines de riches industriels, il est vrai que peu nombreuses, commencent à surgir (Kębliny, Grotniki et autres), le développement des localités dans lesquelles les maisons estivales etaient construites déja avant la première guerre avance toujours (Arturówck, Rogi, Ruda Pabianicka); on a aussi commencé à lover les logements (Głowno, Wiśniowa Góra). Mais ce sont avant tout les vraies colonies estivales qui naissent aux environs de Łódź: la ville-forêt de Kolımna, la ville-jardin de Sokolniki, Tuszyn-Forêt, Grotniki. Ces dernières dans le:irs dispositions spatialos exploitaient l'idée des villes-jardins de E. Howard, très à la mode à l'époque. 
Dans les premières années après la deuxième guerre mondiale les colonies estivales de la zone suburbaine de Łódź, changées en colonies d'habitation, limitent ou, dans certains cas, perdent leur caractère, cessant d'être les centres de repos. Seulement vers la moitié des années soixante naît et se développe dynamiquement la pression sociale visant à la possession d'une parcelle et dans ces conditions a lieu 1c développement de la colonisation de repas la plus dynamique dans l'histoire de la zone suburbaine de Łódź.

En 1966, dans la zone suburbaine de la ville, on a enregistré 2840 parcelles estivales et dix ans après - 6168. La nouvelle colonisation estivale surgissant spontanément a pris possession de plusieurs villages dans les environs de Łódż, en occupant les terrains de paysans lotis souvent contre le droit. Comme exemple d'un tel village, dans le travail, on a présenté Janówka.

Les recherches minutieuses menées en 1979 par A. Matczak (1985) ont démontré que dans la zone suburbaine de Édź il y avait 282 villages et 10 villes remplissant les fonctions de repos développées différemment. Seuls les 9 villages ont pleinement développé ces fonctions, le degré du développement de celles-ci dans les 54 villages est moyen ou haut.

Les résultats des recherches faites ont démontré qu'avec le temps changent le rôle et l'importance de la colonisation de repos dans la zone, suburbaine de Łódź. L'histoire de la colonisation de repos pendant 80 ans sur le terrain examiné permet de constater le rôle significatif de la colonisation dans le processus de l'urbanisation des terrains suburbains et la succession spatiale de la fonction de repos fortement développée aux environs de kódz.

Traduit par Lucjan Kowalski

\section{SUMMARY}

The aim of this article is to explain the genesis of the recreational settlement system on the areas surrounding Łódż, its identification, and determination of stages and directions in development of this settlement form.

Łódź due to its genesis, rate of development and complexity of social structures has many individual characteristics, which finds its reflection also in the recreational settlement system being developed in its surroundings.

Development of the recreational settlements on the areas surrounding Eódź can be divided into three stages: 1) before the First World War; 2) the interwar period; and 3) after the Second World War.

In the period before the First World War, there had been erected on the area under study the finst, not numerous and individual residential buildings by the richest industrialists (Julianów, Łagiewniki), and the first recreational centres, very awkward in their town-planning aspects (Arturówek, Rogi, Ruda Pabianicka) located a short distance from the centre of Eódz. There had appeared also the first attempts at utilization of the network of villages for recreational purposes.

Mainly forested areas, most often pine forests on hills and elevations outside Łódź, situated in the vicinity of railway lines and suburban tram-lines, had been utilized in this period for recreational purposes.

In the interwar period, and especially in its second half, a dynamic expansion of various forms of recreational settlements took place on the area under study. There 
continued to appear new although not numerous suburban residences of rich industrialists (Kębliny, Grotniki, and others). This was accompanied by development of localities, in which still before the First World-War had begun to appear recreational facilities (Arturówek, Rogi, Ruda Pabianicka), or holiday accomodation had begun to be rented (Głowno, Wiśniowa Góra). However, it should be noted Hvat during this period original recreational centres were created in the surroundings of Łódź: Town-Forest Kolumna, Town-Garden Sokolniki, Tuszyn Forest, and Grotniki. In their spatial lay-out, they were responding to E. Howard's idea of "towns-gardens" quite fashionable in Poland at that time.

The firs: years following the Second World War witnessed restriction or even decay in some cases of the recreational function in the former recreation localities of the suburban zone of Łódż, which were changed into housing districts. It was not until the mid-sixties, that a strong social pressure to have a plot of land and a summer cottage outside the place of permanent residence appeared and was intensified dynamically. In these conditions, there began the most dynamic development of recreational settlements in the entire history of the suburban zone of Eódź.

In this zone, there were recorded 2840 recreational plots in 1966, and as many as 6168 ten years later. The spontaneously developing new recreational settlements encompassed many suburban villages at this time utilizing divided peasant lands, sometimes illegally. An example of such a village discussed in the article is Janówka.

Detailed studies carried out in 1979 by A. Matczak (1985) revealed that in the suburban zone of Lódż there were 282 villages and 10 towns characterized with their recreational function developed to a different degree. In this number, 9 villaged had this function well developed, and further 54 villages - developed to a medium or strong degree.

The performed studies revealed changeability in time of the role and significance of recreational settlements in the suburban zone of Łódź. Over 80-year history of recreational settlements on the area under study points at an important role played by them in the urbanization process of suburban areas, and a strongly developed spatial succession of the recreational function in the surroundings of this town.

Translated by Leszek Podbielski 